\title{
Distribution of Different Forms of Aluminium in Clay Fraction of Paddy and Associated Non-Paddy Soils of Assam
}

\author{
Shraddha Mohanty ${ }^{1 *}$, R.M. Karmakar ${ }^{1}$, Veena Bharati ${ }^{2}$, \\ Soumya Pattnaik ${ }^{3}$ and Pooja Biswas ${ }^{4}$ \\ ${ }^{1}$ Department of Soil Science, Faculty of Agriculture, Assam Agricultural University, \\ Jorhat-785013, Assam, India \\ ${ }^{2}$ Department of Agronomy, BAU, Sabour-813210, Bihar, India \\ ${ }^{3}$ Department of Soil Science, OUAT, Bhubaneswar-751003, Odisha, India \\ ${ }^{4}$ Department of Vegetable Science, Faculty of Horticulture, BCKV, \\ Mohanpur- 741252, WB, India \\ *Corresponding author
}

\section{A B S T R A C T}

\section{Keywords}

Dithionite extractable, Oxalate extractable, Pyrophosphate extractable

\section{Article Info}

Accepted:

22 October 2019

Available Online:

10 November 2019
Profiles of paddy and associated non-paddy soils of Jorhat (P1, NP1), Golaghat (P2, NP2), Sivasagar (P3, NP3) and Dibrugarh (P4, NP4) districts of Assam were investigated for different forms of aluminium $(\mathrm{Al})$ : total $\left(\mathrm{Al}_{\mathrm{t}}\right)$, dithionite extractable $\left(\mathrm{Al}_{\mathrm{d}}\right)$, pyrophosphate extractable $\left(\mathrm{Al}_{\mathrm{p}}\right)$ and oxalate extractable $\left(\mathrm{Al}_{\mathrm{o}}\right)$ in the clay fraction. Total $\mathrm{Al}\left(\mathrm{Al}_{\mathrm{t}}\right)$, dithionite extractable $\mathrm{Al}\left(\mathrm{Al}_{\mathrm{d}}\right)$ and oxalate extractable $\mathrm{Al}\left(\mathrm{Al}_{\mathrm{o}}\right)$ in clay fraction was slightly higher in paddy soils as compared to non-paddy soils whereas pyrophosphate extractable $\mathrm{Al}\left(\mathrm{Al}_{\mathrm{p}}\right)$ showed a reverse trend. $\mathrm{Al}_{\mathrm{d}}$ formed major portion of total aluminium content in clay fraction $\left(\mathrm{Al}_{\mathrm{t}}\right)$ followed by $\mathrm{Al}_{\mathrm{p}}$ and $\mathrm{Al}_{\mathrm{o}}$ in both paddy and non-paddy soils. Crystalline aluminium oxide $\left(\mathrm{Al}_{\mathrm{d}}-\mathrm{Al}_{\mathrm{o}}\right)$, amorphous inorganic $\left(\mathrm{Al}_{\mathrm{o}}-\mathrm{Al}_{\mathrm{p}}\right)$ and silicate aluminium $\left(\mathrm{Al}_{\mathrm{t}}-\mathrm{Al}_{\mathrm{d}}\right)$ in clay fraction was found to be higher in paddy soils than non-paddy soils. Also, irrespective of the land use, the content of different forms of $\mathrm{Al}$ in the clay fraction was irregular with depth. $\mathrm{Al}_{\mathrm{d}} / \mathrm{Al}_{\mathrm{t}}$ was found to be slightly higher in non paddy soil than that of paddy soil. Different fraction of organic carbon and the content of clay had a strong influence on the distribution of forms of $\mathrm{Al}$ in the clay fraction of soil. The results also revealed that there was equilibrium in different fractions of this element.

\section{Introduction}

Paddy is cultivated under wet conditions. Specific practices (submergence, puddling etc.) involved rice cultivation bring about changes in the morphological and physicochemical characteristics of the original profile to a variable extent. The degree to which such 
changes are superimposed on the original material depends on the soil material, pedogenic processes active in the area, the degree of evolution of the soil and certain management practices (Moormann, 1981). Some studies suggest that periodic irrigation, drainage, fertilization and tillage during the processes of rice production have resulted in rapid changes in soil characteristics. Paddy soils had lower $\mathrm{pH}$ and higher organic matter content than their non-rice growing counterparts (Jondhale and Prasad, 2006). Hydromorphic condition developed in paddy soils may result in formation of an E (eluvial) horizon below the upper A (alluvial) horizon due to clay mineral structural change and leaching of $\mathrm{Fe}, \mathrm{Al}, \mathrm{Mn}$ (Brinkman, 1970; Kyuma, 2004), as well as the concentration of clay, silt and the formation of anomalous clay pedofeatures on microscopic form down the profile (He et al., 2010; Miura et al., 1992).

During soil development and weathering iron and aluminium are released and reprecipitated as amorphous or crystalline oxides, hydroxides or oxhydroxides (Guertal, 1994). Pedological study usually deals with the contents of crystalline and amorphous Al oxides. So, the aim of this study was to determine the content and relations of different forms of $\mathrm{Al}$ in clay fraction of paddy and associated non-paddy soils considering their significance both in pedological research and in the context of soil chemistry and environmental studies.

\section{Materials and Methods}

Mono cropped paddy growing areas and associated non-paddy growing areas were selected in the Upper Brahmaputra Valley Zone (UBVZ) of Assam. The climate of the study area is humid sub-tropical characterized by high rainfall (1738.5 to $2649.4 \mathrm{~mm}$ ) and high temperature $\left(24.4\right.$ to $\left.26.7^{\circ} \mathrm{C}\right)$. Representative soil profiles were collected from Jorhat, Golaghat, Sivasagar, Dibrugarh districts (Table 1). Soil samples were collected horizon wise, dried under shade and processed. Based on morphological and physicochemical characteristics, the soils were classified as per "Keys to Soil Taxonomy" (Soil Survey Staff, 2014). To separate clay fraction, $10 \mathrm{~g}$ of undisturbed soil sample (horizon-wise) was taken in a $1000 \mathrm{ml}$ long beaker, $300 \mathrm{ml}$ distilled water added and stirred for 30 minutes with the help of magnetic stirrer without adding any chemical. The volume was made to $1000 \mathrm{ml}$ and particles of $<2 \mu$ was separated by sedimentation method (Jackson, 1956) by siphoning. The decanted suspension was centrifuged at $1000 \mathrm{rpm}$ for 15 minutes, washed thrice with distilled water and dried on a water bath. Forms of $\mathrm{Al}$ in the clay fraction of soil was determined by individual extractions with (i) sodium dithionite-citratebicarbonate (Mehra and Jackson, 1960), (ii) $0.2 \mathrm{M}$ ammonium oxalate $(\mathrm{pH} 3.2)$ by shaking for 4 hrs in dark (soil: extractant ratio of 1:20) (McKeague and Day, 1966), (iii) $0.1 \mathrm{~N} \mathrm{Na-}$ pyrophosphate ( $\mathrm{pH} \mathrm{10)}$ by shaking for $16 \mathrm{hrs}$ (soil: extractant ratio of 1:20) (Kononova et al., 1966). Al in the extract was determined colorimetrically using 'Aluminon' reagent (Krishna Murti et al., 1974). Total Al content in clay fraction of soil was carried out following the procedure of Jackson (1973). Simple correlation analysis was followed for some selected variables following the approaches of Snedecor and Cochran (1967).

\section{Results and Discussion}

\section{Distribution of different forms of Al in clay fraction of soil}

The data on distribution of different forms of aluminium in the clay fraction are presented in table 2. Total aluminium content in the clay fraction $\left(\mathrm{Al}_{\mathrm{t}}\right)$ varied from 2.23 to $4.80 \%$ in paddy soils and 1.99 to $3.84 \%$ in non-paddy soils. Irrespective of land use, total aluminium content in the clay fraction $\left(\mathrm{Al}_{\mathrm{t}}\right)$ increased 
with soil depth. The depth of maximum accumulation of $\mathrm{Al}_{t}$ in soil profiles varied from soil to soil. The $\mathrm{Al}_{\mathrm{t}}$ was significantly negatively correlated with bulk density $(\mathrm{r}=$ $\left.0.466^{* *}\right)$ and soil $\mathrm{pH}$ $\left(\mathrm{r}=-0.535^{* *}\right)($ Table 3$)$.

Citrate-Bicarbonate-Dithionite extracts both non-crystalline and crystalline $\mathrm{Al}$ oxides. The amount of dithionite extractable aluminium in the clay fraction $\left(\mathrm{Al}_{\mathrm{d}}\right)$ varied from 0.06 to 0.43 $\%$ in paddy soils and 0.04 to $0.39 \%$ in nonpaddy soils (Table 2). Irrespective of land use, distribution of $\mathrm{Al}_{\mathrm{d}}$ in the clay fraction was irregular throughout the profiles. The $\mathrm{Al}_{\mathrm{d}}$ formed major portion of total aluminium $\left(\mathrm{Al}_{\mathrm{t}}\right)$ content in the clay fraction constituting 1.54 to $10.15 \%$ in paddy soils and 1.52 to $11.25 \%$ in non-paddy soils. The $\mathrm{Al}_{\mathrm{d}}$ was negatively correlated with soil $\mathrm{pH}\left(\mathrm{r}=-0.291^{*}\right)$ (Table 3$)$.

Oxalate dissolved both "amorphous" and "organically bound" forms of Al, but not the crystalline forms (Parfitt and Childs, 1988). The amount of oxalate extractable aluminium in the clay fraction $\left(\mathrm{Al}_{\mathrm{o}}\right)$ varied from 0.03 to $0.30 \%$ in paddy soils and 0.02 to $0.27 \%$ in non-paddy soils (Table 2). The amount of $\mathrm{Al}_{\mathrm{o}}$ in the clay fraction was found to be maximum in surface and plow-sole than in other horizons. In general, the surface horizons of paddy soils contained higher amount of oxalate extractable aluminium $\left(\mathrm{Al}_{\mathrm{o}}\right)$ in the clay fraction as compared to surface horizons of non-paddy soils. The $\mathrm{Al}_{\mathrm{o}}$ constituted 1.07 to $6.75 \%$ of total aluminium $\left(\mathrm{Al}_{\mathrm{t}}\right)$ content in the clay fraction in paddy soils and 0.81 to $7.15 \%$ in non-paddy soils. The $\mathrm{Al}_{\mathrm{o}}$ was significantly and positively correlated with $\mathrm{OC}_{\text {soil }}$ $\left(\mathrm{r}=0.554^{* *}\right)$ and negatively significantly correlated with bulk density $(\mathrm{r}=-0.443 * *)$ and soil $\mathrm{pH}\left(\mathrm{r}=-0.370^{*}\right)$ (Table 3). Pyrophosphate extractant dissolve Al bound with organic matter (Driscoll et al., 1985). The amount of pyrophosphate extractable aluminium in the clay fraction $\left(\mathrm{Al}_{\mathrm{p}}\right)$ varied from 0.02 to $0.23 \%$ in paddy soils and 0.01 to $0.31 \%$ in nonpaddy soils (Table 2). The vertical distribution of pyrophosphate extractable aluminium in the clay fraction $\left(\mathrm{Al}_{\mathrm{p}}\right)$ decreased with depth. The $\mathrm{Al}_{\mathrm{p}}$ constituted 0.35 to $5.98 \%$ of total aluminium $\left(\mathrm{Al}_{\mathrm{t}}\right)$ content in the clay fraction in paddy soils and 0.57 to $9.78 \%$ in non-paddy soils. The $\mathrm{Al}_{\mathrm{p}}$ was significantly and positively correlated with OC $\left(\mathrm{r}=0.750^{* *}\right)$ and negatively and significantly correlated with bulk density $\left(\mathrm{r}=-0.438^{*}\right)$ and soil $\mathrm{pH}(\mathrm{r}=$ $0.370 *$ ) (Table 3).

Table.1 Site characteristics of the study area

\begin{tabular}{|c|c|c|c|c|}
\hline Profile No. & Land use & Location & Latitude & Longitude \\
\hline \multicolumn{5}{|c|}{ Jorhat district } \\
\hline P1 & Paddy & Titabar & $26^{0} 34.366^{\prime} \mathrm{N}$ & $094^{0} 10.737^{\prime} \mathrm{E}$ \\
\hline NP1 & Non paddy & Titabar & $26^{0} 34.383^{\prime} \mathrm{N}$ & $094^{0} 11.027^{\prime} \mathrm{E}$ \\
\hline \multicolumn{5}{|c|}{ Golaghat district } \\
\hline P2 & Paddy & Maheema & $26^{0} 36.014^{\prime} \mathrm{N}$ & $94^{0} 03.855^{\prime} \mathrm{E}$ \\
\hline NP2 & Non paddy & Maheema & $26^{0} 40.810^{\prime} \mathrm{N}$ & $93^{0} 59.157^{\prime} \mathrm{E}$ \\
\hline \multicolumn{5}{|c|}{ Sivasagar district } \\
\hline P3 & Paddy & Charing & $26^{0} 13.426^{\prime} \mathrm{N}$ & $091^{0} 38.559^{\prime} \mathrm{E}$ \\
\hline NP3 & Non paddy & Charing & $26^{0} 54.529^{\prime} \mathrm{N}$ & $094^{0} 33.937^{\prime} \mathrm{E}$ \\
\hline \multicolumn{5}{|c|}{ Dibrugarh district } \\
\hline P4 & Paddy & Khowang & $27^{0} 14.915^{\prime} \mathrm{N}$ & $094^{0} 53.287^{\prime} \mathrm{E}$ \\
\hline NP4 & Non paddy & Khowang & $26^{0} 54.530^{\prime} \mathrm{N}$ & 094 $33.938^{\prime} \mathrm{E}$ \\
\hline
\end{tabular}


Table.2 Different forms of aluminium in clay fraction of soil

\begin{tabular}{|c|c|c|c|c|c|c|c|c|c|c|c|c|c|}
\hline \multirow{2}{*}{$\begin{array}{c}\text { Horizon } \\
\text { Designation }\end{array}$} & \multirow{2}{*}{$\begin{array}{l}\text { Depth } \\
(\mathrm{cm})\end{array}$} & \multirow{2}{*}{$\begin{array}{l}\mathbf{A l}_{\mathbf{t}} \\
(\%)\end{array}$} & \multirow{2}{*}{$\begin{array}{l}\mathbf{A l}_{\mathbf{d}} \\
(\%)\end{array}$} & \multirow{2}{*}{$\begin{array}{l}\mathrm{Al}_{\mathbf{0}} \\
(\%)\end{array}$} & \multirow{2}{*}{$\begin{array}{l}\mathrm{Al}_{\mathrm{p}} \\
(\%)\end{array}$} & \multicolumn{3}{|c|}{$\%$ of total $\mathrm{Al}$ in clay fraction } & \multirow{2}{*}{$\begin{array}{c}\text { crystalline } \\
\left(\mathbf{A l}_{\mathbf{d}}-\mathbf{A l}_{\mathbf{0}}\right) \\
(\%)\end{array}$} & \multirow{2}{*}{$\begin{array}{c}\text { amorphous } \\
\text { inorganic( }\left(\mathbf{A l}_{0}-\right. \\
\left.\mathbf{A l})_{p}\right)_{(\%)}^{-}\end{array}$} & \multirow{2}{*}{$\begin{array}{l}\text { Silicate } \\
\qquad\left(\mathbf{A} \mathbf{l}_{\mathbf{t}^{-}}\right. \\
\left.\mathbf{A l}_{\mathbf{d}}\right)_{(\%)}\end{array}$} & \multirow[t]{2}{*}{$\mathbf{A} \mathbf{l}_{\mathrm{d}} / \mathbf{A} \mathbf{l}_{\mathrm{t}}$} & \multirow[t]{2}{*}{$\mathbf{A l}_{\mathbf{0}} / \mathrm{Al}_{\mathrm{d}}$} \\
\hline & & & & & & $\mathbf{A} \mathbf{l}_{\mathrm{d}}$ & $\mathbf{A l}_{\mathbf{o}}$ & $\mathbf{A l}_{\mathrm{p}}$ & & & & & \\
\hline \multicolumn{14}{|c|}{ P1 (Titabar - Paddy soil): Typic Epiaqualfs } \\
\hline Ap & $0-25$ & 3.96 & 0.31 & 0.21 & 0.23 & 7.89 & 5.28 & 5.91 & 0.10 & -0.02 & 3.65 & 0.08 & 0.67 \\
\hline BA & $25-35$ & 4.45 & 0.35 & 0.30 & 0.19 & 7.91 & 6.75 & 4.25 & 0.05 & 0.11 & 4.10 & 0.08 & 0.85 \\
\hline Bt1 & $35-90$ & 4.77 & 0.08 & 0.18 & 0.06 & 1.78 & 3.75 & 1.21 & -0.09 & 0.12 & 4.69 & 0.02 & 2.11 \\
\hline Bt2 & $90-125$ & 4.80 & 0.07 & 0.13 & 0.04 & 1.54 & 2.64 & 0.84 & -0.05 & 0.09 & 4.73 & 0.02 & 1.71 \\
\hline Bt3 & $125-145$ & 4.15 & 0.12 & 0.07 & 0.04 & 2.94 & 1.57 & 0.95 & 0.06 & 0.03 & 4.03 & 0.03 & 0.53 \\
\hline BC & $145-165+$ & 4.43 & 0.13 & 0.07 & 0.05 & 2.87 & 1.48 & 1.02 & 0.06 & 0.02 & 4.30 & 0.03 & 0.52 \\
\hline Wt. mean & & 4.52 & 0.14 & 0.15 & 0.08 & 3.30 & 3.39 & 1.97 & -0.01 & 0.07 & 4.38 & 0.03 & 1.35 \\
\hline \multicolumn{14}{|c|}{ NP1 (Titabar - Non-paddy soil): Aeric Epiaqualfs } \\
\hline Ap & $0-15$ & 3.15 & 0.28 & 0.15 & 0.31 & 8.95 & 4.81 & 9.78 & 0.13 & -0.16 & 2.87 & 0.09 & 0.54 \\
\hline $\mathbf{A B}$ & $15-35$ & 3.84 & 0.39 & 0.27 & 0.21 & 10.11 & 7.15 & 5.56 & 0.11 & 0.06 & 3.45 & 0.10 & 0.71 \\
\hline Bt1 & $35-80$ & 3.51 & 0.09 & 0.10 & 0.06 & 2.55 & 2.92 & 1.61 & -0.01 & 0.05 & 3.42 & 0.03 & 1.14 \\
\hline Bt2 & 80-130 & 3.04 & 0.05 & 0.07 & 0.03 & 1.52 & 2.34 & 0.86 & -0.02 & 0.04 & 2.99 & 0.02 & 1.54 \\
\hline BC & $130-160+$ & 3.00 & 0.11 & 0.05 & 0.02 & 3.53 & 1.54 & 0.57 & 0.06 & 0.03 & 2.89 & 0.04 & 0.44 \\
\hline Wt. mean & & 3.28 & 0.13 & 0.11 & 0.08 & 3.96 & 3.19 & 2.44 & 0.03 & 0.03 & 3.14 & 0.04 & 1.02 \\
\hline \multicolumn{14}{|c|}{ P2 (Maheema - Paddy soil): Aeric Epiaqualfs } \\
\hline Ap & $0-15$ & 3.64 & 0.28 & 0.20 & 0.22 & 7.61 & 5.45 & 5.98 & 0.08 & -0.02 & 3.36 & 0.08 & 0.72 \\
\hline B & $15-45$ & 3.71 & 0.37 & 0.17 & 0.16 & 9.85 & 4.56 & 4.29 & 0.20 & 0.01 & 3.34 & 0.10 & 0.46 \\
\hline Bt1 & $45-80$ & 4.21 & 0.10 & 0.26 & 0.06 & 2.34 & 6.29 & 1.36 & -0.17 & 0.21 & 4.11 & 0.02 & 2.69 \\
\hline Bt2 & $80-110$ & 3.85 & 0.11 & 0.16 & 0.05 & 2.81 & 4.12 & 1.21 & -0.05 & 0.11 & 3.74 & 0.03 & 1.47 \\
\hline BC & $110-165$ & 3.75 & 0.06 & 0.10 & 0.05 & 1.47 & 2.55 & 1.28 & -0.04 & 0.05 & 3.69 & 0.02 & 1.74 \\
\hline Wt. mean & & 3.85 & 0.15 & 0.17 & 0.09 & 3.98 & 4.26 & 2.26 & -0.02 & 0.08 & 3.70 & 0.04 & 1.56 \\
\hline \multicolumn{14}{|c|}{ NP2 (Maheema - Non-paddy soil): Ultic Hapludalfs } \\
\hline Ap & $0-10$ & 2.20 & 0.18 & 0.07 & 0.13 & 8.11 & 3.12 & 5.77 & 0.11 & -0.06 & 2.02 & 0.08 & 0.39 \\
\hline AB & $10-25$ & 2.80 & 0.21 & 0.11 & 0.10 & 7.36 & 3.95 & 3.64 & 0.10 & 0.01 & 2.59 & 0.07 & 0.54 \\
\hline Bt1 & $25-60$ & 3.22 & 0.09 & 0.10 & 0.09 & 2.74 & 3.05 & 2.67 & -0.01 & 0.01 & 3.13 & 0.03 & 1.11 \\
\hline Bt2 & $60-85$ & 3.05 & 0.08 & 0.05 & 0.05 & 2.55 & 1.80 & 1.55 & 0.02 & 0.01 & 2.97 & 0.03 & 0.71 \\
\hline Bt3 & $85-125$ & 2.74 & 0.06 & 0.05 & 0.04 & 2.35 & 1.66 & 1.39 & 0.02 & 0.01 & 2.68 & 0.02 & 0.71 \\
\hline BC & $125-160$ & 2.96 & 0.06 & 0.02 & 0.03 & 2.16 & 0.81 & 1.06 & 0.04 & -0.01 & 2.90 & 0.02 & 0.38 \\
\hline Wt. mean & & 2.91 & 0.09 & 0.06 & 0.06 & 3.25 & 2.11 & 2.11 & 0.03 & 0.00 & 2.82 & 0.03 & 0.69 \\
\hline
\end{tabular}




\begin{tabular}{|c|c|c|c|c|c|c|c|c|c|c|c|c|c|}
\hline \multirow{2}{*}{$\begin{array}{c}\text { Horizon } \\
\text { Designation }\end{array}$} & \multirow{2}{*}{$\begin{array}{c}\text { Depth } \\
\text { (cm) }\end{array}$} & \multirow{2}{*}{$\begin{array}{l}\mathbf{A l}_{\mathbf{t}} \\
(\%)\end{array}$} & \multirow{2}{*}{$\begin{array}{r}\mathbf{A l}_{\mathbf{d}} \\
(\%)\end{array}$} & \multirow{2}{*}{$\begin{array}{c}\mathbf{A l}_{\mathbf{o}} \\
(\%)\end{array}$} & \multirow{2}{*}{$\begin{array}{l}\mathrm{Al}_{\mathrm{p}} \\
(\%)\end{array}$} & \multicolumn{3}{|c|}{$\%$ of total Al in clay fraction } & \multirow{2}{*}{$\begin{array}{c}\text { crystalline } \\
\left(\mathbf{A l}_{\mathbf{d}}-\mathbf{A l}_{\mathbf{o}}\right) \\
(\%)\end{array}$} & \multirow{2}{*}{$\begin{array}{c}\text { amorphous } \\
\text { inorganic( }\left(\mathbf{A l}_{\mathbf{0}}-\right. \\
\left.\mathbf{A l}_{\mathbf{p}}\right)_{(\%)}\end{array}$} & \multirow{2}{*}{$\begin{array}{l}\text { Silicate } \\
\qquad\left(\mathbf{A l}_{\mathbf{t}^{-}}\right. \\
\left.\mathbf{A l}_{\mathbf{d}}\right)_{(\%)}\end{array}$} & \multirow[t]{2}{*}{$\mathbf{A l} \mathbf{l}_{\mathrm{d}} / \mathbf{A l}_{\mathbf{t}}$} & \multirow[t]{2}{*}{$\mathbf{A l}_{\mathbf{0}} / \mathbf{A l} \mathbf{l}_{c}$} \\
\hline & & & & & & $\mathbf{A l}_{\mathbf{d}}$ & $\mathbf{A l}_{\mathbf{o}}$ & $\mathbf{A l}_{\mathbf{p}}$ & & & & & \\
\hline \multicolumn{14}{|c|}{ P3 (Charing - Paddy soil): Aeric Epiaqualfs } \\
\hline Ap & $0-15$ & 3.87 & 0.38 & 0.04 & 0.08 & 9.77 & 1.07 & 2.10 & 0.34 & -0.04 & 3.49 & 0.10 & 0.11 \\
\hline $\mathbf{A B}$ & $15-30$ & 4.22 & 0.43 & 0.22 & 0.07 & 10.15 & 5.21 & 1.77 & 0.21 & 0.15 & 3.79 & 0.10 & 0.51 \\
\hline Bt1 & $30-65$ & 4.75 & 0.41 & 0.17 & 0.08 & 8.69 & 3.66 & 1.58 & 0.24 & 0.10 & 4.34 & 0.09 & 0.42 \\
\hline Bt2 & $65-100$ & 4.27 & 0.09 & 0.08 & 0.04 & 2.15 & 1.85 & 0.96 & 0.01 & 0.04 & 4.18 & 0.02 & 0.86 \\
\hline Bt3 & $100-140$ & 4.68 & 0.17 & 0.15 & 0.02 & 3.57 & 3.21 & 0.51 & 0.02 & 0.13 & 4.51 & 0.04 & 0.90 \\
\hline $\mathbf{C}$ & $140-170$ & 4.71 & 0.16 & 0.11 & 0.02 & 3.48 & 2.33 & 0.35 & 0.05 & 0.09 & 4.55 & 0.04 & 0.67 \\
\hline Wt. mean & & 4.50 & 0.24 & 0.13 & 0.05 & 5.44 & 2.86 & 1.05 & 0.11 & 0.08 & 4.26 & 0.05 & 0.65 \\
\hline \multicolumn{14}{|c|}{ NP3 (Charing - Non-paddy soil): Aeric Epiaqualfs } \\
\hline Ap & $0-15$ & 2.84 & 0.32 & 0.03 & 0.04 & 11.25 & 1.01 & 1.33 & 0.29 & -0.01 & 2.52 & 0.11 & 0.09 \\
\hline $\mathbf{A B}$ & $15-30$ & 2.96 & 0.36 & 0.16 & 0.10 & 12.33 & 5.31 & 3.28 & 0.21 & 0.06 & 2.60 & 0.12 & 0.43 \\
\hline Bt1 & $30-65$ & 2.98 & 0.26 & 0.07 & 0.10 & 8.56 & 2.51 & 3.26 & 0.18 & -0.02 & 2.72 & 0.09 & 0.29 \\
\hline Bt2 & $65-100$ & 2.75 & 0.20 & 0.05 & 0.05 & 7.34 & 1.71 & 1.88 & 0.15 & 0.00 & 2.55 & 0.07 & 0.23 \\
\hline BC & $100-145$ & 1.99 & 0.07 & 0.06 & 0.03 & 3.28 & 2.87 & 1.54 & 0.01 & 0.03 & 1.92 & 0.03 & 0.88 \\
\hline $\mathbf{C}$ & $145-165$ & 2.13 & 0.07 & 0.05 & 0.01 & 3.34 & 2.55 & 0.67 & 0.02 & 0.04 & 2.06 & 0.03 & 0.76 \\
\hline Wt. mean & & 2.54 & 0.19 & 0.06 & 0.05 & 6.82 & 2.56 & 2.01 & 0.12 & 0.01 & 2.36 & 0.07 & 0.49 \\
\hline \multicolumn{14}{|c|}{ P4 (Khowang - Paddy soil): Aeric Epiaqualfs } \\
\hline Ap & $0-10$ & 2.23 & 0.13 & 0.03 & 0.06 & 6.02 & 1.56 & 2.82 & 0.10 & -0.03 & 2.10 & 0.06 & 0.26 \\
\hline $\mathbf{B A}$ & $10-35$ & 3.56 & 0.32 & 0.15 & 0.13 & 8.97 & 4.22 & 3.55 & 0.17 & 0.02 & 3.24 & 0.09 & 0.47 \\
\hline Bt1 & $35-65$ & 3.14 & 0.11 & 0.10 & 0.05 & 3.66 & 3.16 & 1.58 & 0.02 & 0.05 & 3.03 & 0.04 & 0.86 \\
\hline Bt2 & 65-105 & 2.91 & 0.08 & 0.14 & 0.04 & 2.64 & 4.75 & 1.39 & -0.06 & 0.10 & 2.83 & 0.03 & 1.80 \\
\hline BC & $105-135$ & 3.28 & 0.09 & 0.04 & 0.04 & 2.81 & 1.18 & 1.13 & 0.05 & 0.00 & 3.19 & 0.03 & 0.42 \\
\hline $\mathbf{C}$ & $135-195$ & 3.24 & 0.10 & 0.07 & 0.04 & 3.14 & 2.28 & 1.28 & 0.03 & 0.03 & 3.14 & 0.03 & 0.73 \\
\hline Wt. mean & & 3.15 & 0.13 & 0.09 & 0.05 & 3.96 & 2.96 & 1.70 & 0.03 & 0.04 & 3.03 & 0.04 & 0.86 \\
\hline \multicolumn{14}{|c|}{ NP4 (Khowang - Non-paddy soil): Typic Dystrudepts } \\
\hline Ap & $0-15$ & 1.99 & 0.17 & 0.03 & 0.07 & 8.44 & 1.32 & 3.62 & 0.14 & -0.05 & 1.82 & 0.08 & 0.16 \\
\hline Bw1 & $15-35$ & 2.12 & 0.18 & 0.06 & 0.09 & 8.67 & 2.88 & 4.18 & 0.12 & -0.03 & 1.94 & 0.09 & 0.33 \\
\hline Bw2 & $35-50$ & 2.55 & 0.11 & 0.05 & 0.05 & 4.44 & 1.98 & 1.94 & 0.06 & 0.00 & 2.44 & 0.04 & 0.45 \\
\hline Bw3 & $50-110$ & 2.44 & 0.04 & 0.04 & 0.05 & 1.78 & 1.56 & 2.06 & 0.01 & -0.01 & 2.40 & 0.02 & 0.88 \\
\hline BC & $110-150$ & 2.28 & 0.07 & 0.03 & 0.05 & 2.89 & 1.38 & 2.19 & 0.03 & -0.02 & 2.21 & 0.03 & 0.48 \\
\hline $\mathbf{C}$ & $150-195$ & 2.41 & 0.06 & 0.05 & 0.05 & 2.54 & 2.01 & 1.96 & 0.01 & 0.00 & 2.35 & 0.03 & 0.79 \\
\hline Wt. mean & & 2.34 & 0.08 & 0.04 & 0.06 & 3.61 & 1.78 & 2.39 & 0.04 & -0.01 & 2.26 & 0.04 & 0.63 \\
\hline
\end{tabular}


Table.3 Correlation coefficients (r) among forms of $\mathrm{Al}$ in clay fraction and other parameters of soil

\begin{tabular}{|c|c|c|c|c|c|c|}
\hline & $\mathbf{A l}_{\mathbf{t}}$ & $\mathbf{A l}_{\mathbf{d}}$ & $\mathbf{A l}_{\mathbf{o}}$ & $\mathbf{A \mathbf { I } _ { \mathbf { p } }}$ & $\mathbf{A l}_{\mathbf{d}} / \mathbf{A l}_{\mathbf{t}}$ & $\mathbf{A l}_{\mathbf{o}} / \mathbf{A l}_{\mathbf{d}}$ \\
\hline $\mathbf{O C}_{\text {soil }}$ & 0.224 & $0.633^{* *}$ & $0.554^{* *}$ & $0.750^{* *}$ & $0.606^{* *}$ & -0.052 \\
\hline Bulk density & $-0.466^{* *}$ & -0.125 & $-0.443^{* *}$ & $-0.438^{* *}$ & 0.022 & $-0.333^{*}$ \\
\hline $\mathbf{p H}$ & $-0.535^{* *}$ & $-0.291^{*}$ & $-0.370^{*}$ & $-0.370^{*}$ & -0.138 & -0.059 \\
\hline $\mathbf{A l}_{\mathbf{d}}$ & 0.290 & 1.000 & & & & \\
\hline $\mathbf{A l}_{\mathbf{o}}$ & $0.619^{* *}$ & $0.534^{* *}$ & 1.000 & & & \\
\hline $\mathbf{A l}_{\mathbf{p}}$ & 0.110 & $0.620^{* *}$ & $0.573^{* *}$ & 1.000 & & \\
\hline $\mathbf{A l}_{\mathbf{d}} / \mathbf{A l}_{\mathbf{t}}$ & -0.061 & $0.914^{* *}$ & $0.300^{*}$ & $0.596^{* *}$ & 1.000 & \\
\hline $\mathbf{A l}_{\mathbf{o}} / \mathbf{A l}_{\mathbf{d}}$ & $0.367^{*}$ & -0.435 & $0.414^{* *}$ & -0.162 & $-0.580^{* *}$ & 1.000 \\
\hline
\end{tabular}

r-value for $44 \mathrm{df}=0.291$ at $\mathrm{P}_{0.05}$ and 0.376 at $\mathrm{P}_{0.01}$

The amount of crystalline aluminium oxide $\left(\mathrm{Al}_{\mathrm{d}}-\mathrm{Al}_{\mathrm{o}}\right)$ in the clay fraction varied from -0.17 to $0.34 \%$ in paddy soils and -0.02 to $0.29 \%$ in non-paddy soils. This may be due to higher organic $\mathrm{C}$ in paddy soils which inhibits crystallization. The amount of amorphous inorganic aluminium $\left(\mathrm{Al}_{\mathrm{o}}-\mathrm{Al}_{\mathrm{p}}\right)$ in the clay fraction varied from -0.04 to $0.21 \%$ in paddy soils and -0.16 to $0.06 \%$ in non-paddy soils (Table 2). Negative values in some of the soils indicate that whole of the amorphous Al is complexed with organic matter in these soils. Distribution of both crystalline and amorphous form of aluminium was irregular with soil depth. In general, the surface horizons of paddy soils contained higher amount of amorphous inorganic aluminium $\left(\mathrm{Al}_{\mathrm{o}}-\mathrm{Al}_{\mathrm{p}}\right)$ in the clay fraction as compared to surface horizons of non-paddy soils.

The amount of silicate aluminium $\left(\mathrm{Al}_{\mathrm{t}}-\mathrm{Al}_{\mathrm{d}}\right)$ in the clay fraction varied from 2.10 to $4.73 \%$ in paddy soils and 1.92 to $3.45 \%$ in non-paddy soils (Table 2). Distribution of this form of aluminium increased with depth and then decreased.

In general, the surface horizons of paddy soils contained higher amount of silicate aluminium $\left(\mathrm{Al}_{\mathrm{t}}-\mathrm{Al}_{\mathrm{d}}\right)$ in the clay fraction as compared to surface horizons of non-paddy soils.
The results indicate that irrespective land use, various forms of $\mathrm{Al}$ in the clay fraction followed the descending order of $A l_{d}>A l_{p}>A l_{o}$. With increasing soil acidity, all the forms of aluminium $\left(\mathrm{Al}_{\mathrm{t}}, \mathrm{Al}_{\mathrm{d}}, \mathrm{Al}_{\mathrm{o}}, \mathrm{Al}_{\mathrm{p}}\right)$ in the clay fraction increased as evident from significant negative correlation between forms of aluminium and soil pH (Table 3).

On the other hand, amount of all the forms of aluminium in clay fraction increased with soil organic $\mathrm{C}$ as evident from the significant positive correlations of forms of $\mathrm{Al}$ and organic C (Table3). The crystalline Al oxides increased at the expense of the poorly crystalline forms with increasing soil age as indicated by the ratios of $\mathrm{Al}_{\mathrm{o}} / \mathrm{Al}_{\mathrm{d}}$ (Mahaney and Fahey, 1988).

Slightly higher amount of all forms of Al has been observed in the clay fraction of paddy soils as compared to non-paddy soils. This may be attributed to relative variation in total Al $\left(\mathrm{Al}_{\mathrm{t}}\right)$ in these soils due to differential quantitative existence of alumino-silicates in the parent material and occurrence of more amount of soil organic $\mathrm{C}$ in paddy soils.

\section{Aluminium in relation to pedogenesis}

The behaviour of pedogenic aluminium in paddy soils is different from that of $\mathrm{Fe}$ and 
Mn. Aluminium shows relative persistence to redox changes (Lantimer, 1952) while at the same time, $\mathrm{pH}$ governs its sensitivity and mobility in soils (Table 3 ).

A little movement of $\mathrm{Al}$ in soils under paddy cultivation has been observed in the present study (Table 2). Within a profile, $\mathrm{Al}_{\mathrm{d}} / \mathrm{Al}_{\mathrm{t}}$ ratio showed higher values for the upper horizons than the lower horizons irrespective of land use. This clearly showed the influence of organic $\mathrm{C}$ in soil and clay fractions and $\mathrm{pH}$ of the soil (Table 3).

The $\mathrm{Al}_{\mathrm{o}} / \mathrm{Al}_{\mathrm{d}}$ ratio in clay fraction varied from 0.11 to 2.69 in paddy soils and 0.16 to 1.54 in non-paddy soils. On the profile weighted mean basis, paddy soils had higher $\mathrm{Al}_{\mathrm{o}} / \mathrm{Al}_{\mathrm{d}}$ ratio in clay fraction than the associated nonpaddy soils.

Distribution of $\mathrm{Al}$ in clay fraction is greatly influenced by the soil genesis and nature and degree of pedogenic processes. Such processes vary among paddy and non-paddy soils due to specific practices undertaken during paddy cultivation. Higher amount of $\mathrm{Al}_{\mathrm{d}}$ and $\mathrm{Al}_{\mathrm{o}}$ were associated with clay in the paddy soils than its non-paddy counterpart. Dominance of crystalline form of $\mathrm{Al}$ in the clay fraction over amorphous and silicate form indicate structural distortion due to intense weathering in paddy soil. Crystalline $\mathrm{Al}$ oxide, amorphous inorganic $\mathrm{Al}$ and silicate $\mathrm{Al}$ in clay fraction was found to be higher in paddy soils than non-paddy soils. This information can be necessary for better management of these contrasting but closely associated soils.

\section{References}

Brinkman, R. 1970. Ferrolysis, a hydromorphic soil forming process. Geoderma, 3: 199-206.

Driscoll, C.J., Van Breemen, N., Mulder, J. 1985. Aluminum chemistry in a forested spodosol. Soil Science Society of America Journal, 49: 437-444.

Guertal, W.R. 1994. The Pedologic Nature of Weathered Rock. In: Cremeens, D.L., et al., Eds., Whole Regolith Pedology, SSSA, Madison. Pp 21-40.

He, H., Ma, Y., Zhu, J., Yuan, P. and Qing, Y. 2010. Organoclays prepared from montmorillonites with different cation exchange capacity and surfactant configuration. Applied clay science, 48: 67-72.

Jackson, M. L. 1956. Soil Chemical AnalysisAdvanced course. Published by the author. Department of Soil Science, University of Wisconsin, Madison, WI.

Jackson, M. L. 1973. Soil Chemical Analysis. Prentice Hall of India Pvt. Ltd., New Delhi.

Jondhale, D.G. and Prasad, J. 2006. Characteristics of rainfed rice and associated non-rice shrink-swell soils in Central India. Clay Research, 25: 55-67.

Kononova, M. M. 1966. In Soil Organic Matter, $2^{\text {nd }}$ ed., Pergamom Press, Oxford. Pp377-426.

Krishna Murti, G. S. R., Sarma, V. A. K. and Rengasamy, P. 1974 Spectrometric determination of aluminium with aluminon. Indian Journal of Technology, 12: 270-271.

Kyuma, K. 2004. Paddy soil science. Kyoto University Press, 280p

Lantimer, W. M. 1952. Oxidation Potentials. $2^{\text {nd }}$ ed. Prentice Hall, Inc. Englewood Cliffs, N. Y. 392p.

Mahaney, W.C., Fahey, B.D. 1988. Extractable $\mathrm{Fe}$ and $\mathrm{Al}$ in late Pleistocene and Holocene paleosols on Niwot Ridge, Colorado Front Range. Catena, 15: 17-26.

McKeague, J.A. and Dey, J.H. 1966. Dithionite and oxalate extractable Fe and $\mathrm{Al}$ as aids in difeerentiating 
various classes of soils. Canadian Journal of Soil Science, 46: 13-22.

Mehra, O. P. and Jackson, M. L. 1960. Iron oxide removal from soils and clays by a dithionite - citrate system buffered with sodium bicarbonate. In 'Clays and Clay Mineral Proc.' $7^{\text {th }}$ Nat. Conf. Monograph.5 Cart Science Series. Pergamon Press, New York. Pp. 283 323.

Miura, K., Tulaphitak, T. and Kyuma, K. 1992. Pedogenetic studies on some selected soils in Northeast Thailand. Soil Science and Plant Nutrition, 38: 485-493.

Moormann, F.R. 1981. The classification of paddy soils as related to soil taxonomy. In Paddy Soils. Institute of Soil Science, Academic Sinica, Nan jing. China, pp. 139-150.

Parfitt, R.L. and Childs, C.W. 1988. Estimation of forms of $\mathrm{Fe}$ and $\mathrm{Al}-\mathrm{A}$ review, and analysis of contrasting soils by dissolution and Mossbauer methods. Australian Journal of Soil Research, 26: 121-144.

Snedecor, G. W. and Cochran, W. G. 1967. Statistical Methods. Oxford and IBH Publ. Co, Calcutta, pp135-198.

Soil Survey Staff. 2014. 'Keys to Soil Taxonomy', Twelfth Edition. (USDA: Washington, D.C.).

\section{How to cite this article:}

Shraddha Mohanty, R.M. Karmakar, Veena Bharati, Soumya Pattnaik and Pooja Biswas. 2019. Distribution of Different Forms of Aluminium in Clay Fraction of Paddy and Associated NonPaddy Soils of Assam. Int.J.Curr.Microbiol.App.Sci. 8(11): 2223-2230.

doi: https://doi.org/10.20546/ijcmas.2019.811.259 